\title{
Characterization of Organism-Sediment Relations Using Sediment Profile Imaging: An Efficient Method of Remote Ecological Monitoring of the Seafloor (Remots ${ }^{\mathrm{TM}}$ System)
}

\author{
Donald C. Rhoads ${ }^{1}$ and Joseph D. Germano ${ }^{2}$ \\ 1 Department of Geology and Geophysics, Yale University, P.O. Box 6666, New Haven, Connecticut 06511, USA \\ ${ }^{2}$ Department of Biology, Yale University, P.O. Box 6666, New Haven, Connecticut 06511, USA
}

\begin{abstract}
A benthic successional model allows interpretation of structures observed in sediment profile images. From these structures, temporal and spatial changes can be deduced in both benthic habitat and its associated fauna. The instrument used for in situ remote monitoring is the RhoadsCande profile photographic camera or its updated version, the video REMOTS (Remote Ecological Monitoring of The Seafloor) system. Sediment profile imaging has been used to characterize an estuarine pollution gradient in Narragansett Bay, Rhode Island and to monitor the 'August Effect' on benthic faunal dynamics in New Haven Harbor, Connecticut (USA). The ability of the profile camera to map rapidly patterns of seafloor disturbance and subsequent faunal change is described for a $1.5 \mathrm{mi}^{2}$ area near the Thimble Islands, Long Island Sound, Connecticut. We discuss the potential application of the REMOTS system for efficient monitoring of dredge-spoil activities and as a reconnaissance mapping tool for detecting change in benthic habitats in the region of outer continental shelf drilling fields.
\end{abstract}

\section{INTRODUCTION}

Ten years ago, sediment profile photography was proposed as an efficient technique for in situ documentation of organism-sediment relations (Rhoads and Cande, 1971). This technique has not gained wide acceptance because it was not supported by theory to interpret sediment profile images. Over the past $5 \mathrm{yr}$, research on organism-sediment relations has become increasingly 'successional' in its approach. This successional perspective has proven to be a major key for interpreting sediment profile images. Although the profile images provide only structural data, the successional model permits one to make inferences about physical, chemical, and biological benthic processes.

The purpose of this paper is not to review advances in organism-sediment research over the past $5 \mathrm{yr}$ (such reviews are presented in Aller, 1982; Rhoads and Boyer, 1982), but to show how benthic successional dynamics can be inferred from sediment-profile images. We hope that this explanation will lead to wider acceptance of this remote imaging technique.

\section{THE SUCCESSIONAL MODEL}

Johnson (1972) was one of the first to present an ecologically realistic model of benthic communities. He pointed out that habitat heterogeneity and smallscale temporal disturbances create a spatial and temporal mosaic: 'In this view, a community is a collection. of the relics of former disasters.' Subsequent investigators (Myers, 1977; Rhoads et al., 1977, 1978; McCall, 1978; Santos and Bloom, 1980; Santos and Simon, 1980; Rhoads and Boyer, 1982) presented data to support Johnson's model.

The following paragraphs describe the successional patterns which may follow from what Johnson called 'former disasters'. The term succession has many connotations in the literature (see McIntosh, 1980 for a discussion of the history of the successional concept). We define primary succession as the predictable appearance of macrobenthic invertebrates belonging to specific functional types following a benthic disturbance. These invertebrates interact with sediment in specific ways. Because functional types are the biolog- 
ical units of interest, our definition does not demand a sequential appearance of particular invertebrate species or genera. This successional model (Rhoads and Boyer, 1982) describes how each successional stage modifies the physical and chemical properties of the sediment in subtidal areas. Sediment profile imaging can remotely detect the results of disturbances* responsible for driving succession, such as bottom erosion or deposition, changes in substratum type, relative changes in levels of dissolved oxygen, and organic decomposition processes.

Fig. 1 shows diagrammatically organism-sediment relations as they develop during succession of a subtidal granular bottom. Most of the information about this shoaling depth of storm waves. However, disturbance assemblages may be found at any water depth, even in abyssal trenches (Jumars and Hessler, 1976).

Small opportunistic tube-dwelling polychaetes or oligochaetes (here identified as Stage 1 succession) are among one of the first macrofaunal components to colonize a new or newly disturbed bottom. These polychaetes are aggregated and may reach densities of $10^{5} \mathrm{~m}^{-2}$ within a few days to weeks after disturbance (McCall, 1977; Rhoads et al., 1978). Alternatively, the opportunistic mactrid bivalve Mulinia lateralis may colonize locally the bottom in densities of $10^{3}$ to $10^{4} \mathrm{~m}^{-2}$. The pioneering species which colonize a disturbed bottom may vary, depending on substratum
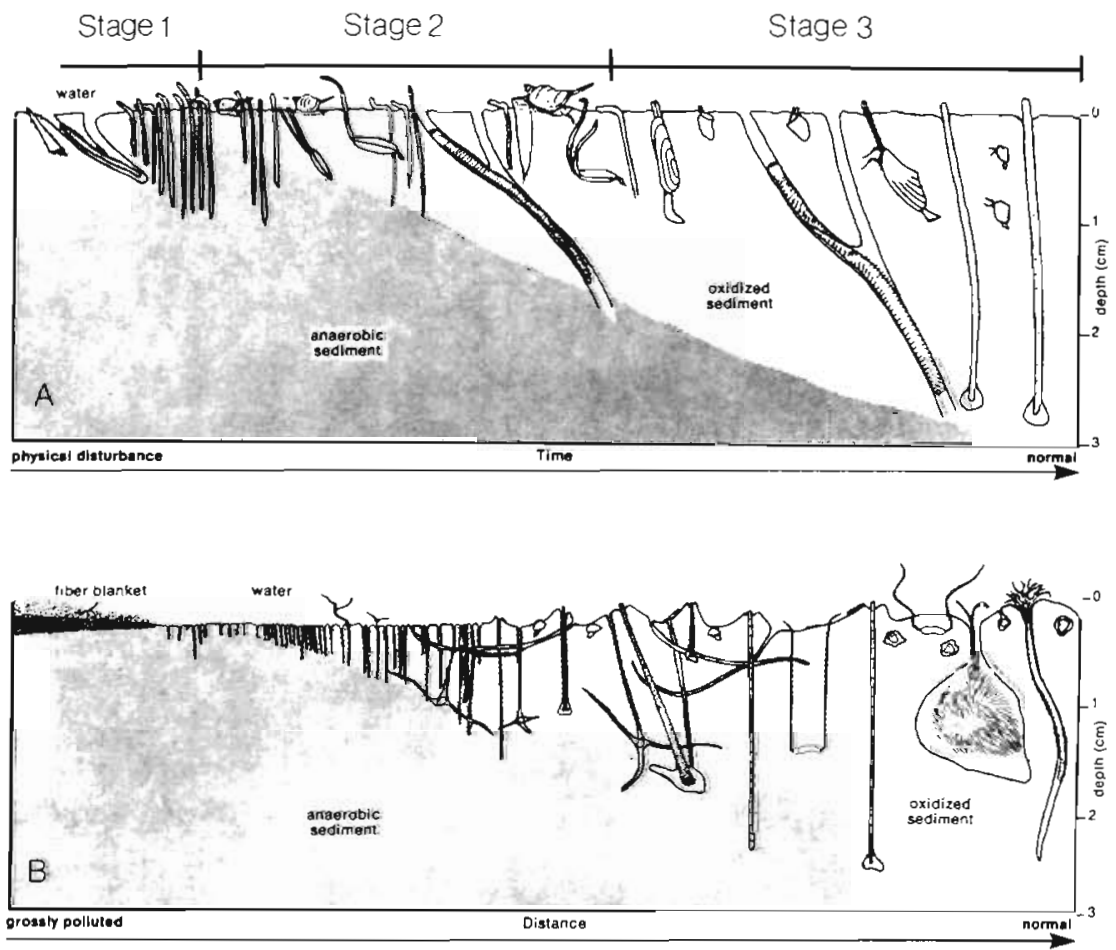

Fig. 1. Development of organism-sediment relations over time following a major physical disturbance (A; modified from Rhoads et al., 1978) and along a chronic pollution gradient $(B$; modified from Pearson and Rosenberg, 1978). Pioneering species ( $\mathrm{left} \mathrm{side}$ ) tend to be tubicolous or otherwise sedentary organisms that live near the sediment surface and feed at the surface or from the water column. Particle bioturbation rates are low and aerated sediment layer is thin. Stage 1, Stage 2 , and Stage 3 seres, as defined in this paper, are delimited in (A). High-order successional stages ( $\mathrm{right}$ side) tend to be dominated by bioturbating infauna that feed at depth within the sediment (Stage 3). Particle bioturbation rates are high and the aerated sediment layer is thick successional pattern comes from muds (e.g. Bagge, 1969; Pearson and Rosenberg, 1978; McCall, 1977; Rhoads et al., 1977, 1978) but major qualitative features of this succession are apparently also shared with sand-dwelling faunas (e.g. Myers, 1977). The following generalizations are drawn from Rhoads and Boyer (1982):

Pioneering stages are most commonly encountered nearshore where the bottom is located above the mean

- For comprehensive reviews of the physical, biological and chemical perturbations that can affect macrofaunal succession, we refer the reader to Pearson and Rosenberg (1978) and Dayton and Oliver (1980) composition, pollutant load, and disturbance intensity. Recruitment also depends on the types of larvae that are available for settling following a disturbance.

Most pioneering species feed near the sediment surface or from the water column. Tube walls or shells serve to isolate the colonizing organisms from the sediment. This is done by controlling the rate of diffusion of ambient pore water solutes into the tube or mantle environment (Aller, 1980)

An organism colonizing a newly disturbed or a 'new' sediment is faced with formidable physiological problems. The pore-water chemistry will be unpredictable, especially the vertical concentration gradients of porewater, metabolites, metal sulphides, dissolved oxy- 
gen ${ }^{\circ}$, and organic decomposition products. High concentrations of reduced compounds in subsurface sediment diffuse across the tube walls and enter the tube interior. Aller (1980) has shown that organisms occupying closely spaced small diameter tubes efficiently share the work (measured as tube irrigation) required to maintain a constant and low concentration of solutes (e.g. $\mathrm{NH}_{4}$ ) in their tubes. The unpredictable chemical and trophic environment below the sediment-water interface may also explain why most pioneering species feed at, or above, the sediment-water interface.

Densely-spaced tubes may also promote sedimentation and protect the sediment surface from scour by water turbulence. When the cross-sectional areas (planar view) of the tubes represent between $1 / 8$ and $1 / 12$ of the area of the seafloor, the bottom may be protected from scour (Eckman et al., 1981). At lower tube area ratios, isolated tubes actually promote bottom scour because of turbulence shed from the tubes. The sedimentary effects of pioneering species are limited to the near surface region of the bottom $(\leq 3 \mathrm{~cm})$. These effects include: (1) Construction of dense tube aggregations which may in turn affect sedimentation or erosion (possibly dictated by tube diameter, tube height, and tube spacing). (2) Fluid bioturbation which consists mainly of pumping water into and out of the bottom through vertically oriented tubes - causes the redox boundary to be deeper than one formed solely by diffusion of oxygen from the overlying water. Particle bioturbation, although present, is of subordinate importance. The depth of theredox boundary can be visually seen as a brown oxidized layer at the surface of the sediment or locally around tube and burrow walls. In sediments high in iron content, this colored layer may not, in many cases, reflect the presence of free molecular oxygen in sediment porewater. Once oxidized, ferric iron may persist long after the associated pore water has been depleted of dissolved oxygen (Revsbech et al., 1979). (3) Surface depositfeeding and suspension-feeding may result in the surface of the bottom being covered with fecal pellets.

In the absence of further physical, chemical, or biological disturbance, early successional tubicolous

\footnotetext{
- Mapping of the depth of the redox potential discontinuity (RPD) below the surface of marine sediments has proven useful for assessing the effect of organic pollution on the benthic ecosystem (Pearson and Stanley, 1979). Cause and effect relationships are complex. In areas of the seafloor experiencing organic enrichment, biological oxygen demand (BOD) and chemical oxygen demand (COD) are highly correlated with organic decomposition. This oxygen demand causes the $E \mathrm{E}=\mathrm{O}$ horizon to rebound toward the sediment surface. The enrichment is also associated with the appearance of pioneering species which are relatively ineffective in exchanging ambient pore water with overlying water, hence the redox remains near the sediment surface
}

assemblages are eventually replaced by infaunal deposit-feeders. This progressive 'infaunalization' can arbitrarily be divided into 2 stages, an intermediate (Stage 2) and equilibrium stage (Stage 3). Typical species appearing in the intermediate Stage 2 assemblage are shallow-dwelling bivalves (e.g. Mulinia lateralis, Tellina agilis) or tubicolous amphipods (e.g. Ampelisca abdita; see Fig. 3).

An equilibrium assemblage is persistent and dominated by infaunal deposit-feeders, many of which are represented by 'head-down' conveyor-belt feeders (sensu Rhoads, 1974). Some of these species are tubicolous (e.g. the polychaete family Maldanidae) but many others are mobile and free-living. Examples of equilibrium assemblages have been described for the Maldanid-Nucula-Syndosmya community in the Clyde Sea (Moore, 1931), the Nucula-Nephtys assemblage in Buzzards Bay (Sanders, 1958; Rhoads and Young, 1970), the Molpadia-Euchone community of Cape Cod Bay (Rhoads and Young, 1971; Young and Rhoads, 1971), the Lumbrineris-Alpheus-Diolodonta community in Kingston Harbor, Jamaica (Wade, 1972), and the Maldane-Amphiura community of Ria de Muros, Spain (Tenore et al., 1982). These equilibrium assemblages are associated with a deeply oxygenated sediment surface where the redox commonly reaches depths of over $10 \mathrm{~cm}$. Feeding is concentrated at, but not limited to, the redox boundary. The redox zone appears to be a region of high microorganism productivity (Yingst and Rhoads, 1980). Both vertical particle mixing and pore water exhange by respiratory pumping are important bioturbational processes. Organismsediment relations are complex and well-developed in equilibrium systems. In summary, the sedimentary effects of equilibrium species in shallow water environments appear to be: (1) The transfer of both water and particles over vertical distances of up to $10-20 \mathrm{~cm}$. (2) Intensive particle mixing produces homogeneously mixed fabrics; many of the particles at and below the sediment surface may be in the form of fecal pellets. (3) Head-down feeding produces void spaces (feeding pockets) at depth within the bottom. (4) Surface microtopography may be featureless and planar if tidal resuspension 'smoothes-over' biologically produced features at the sediment surface; in the absence of this smoothing effect, the surface may be covered with numerous feeding pits, and fecal or excavation mounds.

The above generalizations may require revision as we learn more about how organism-sediment relations develop during succession. This is especially true for subtidal sandy habitats where the successional sequence of functional types has not yet been worked out in detail. Even though the specific species which participate in this successional sequence depend on the 
larval pool, nature of the disturbance, and substratum conditions, they will functionally achieve the same effects over time. Hence, we feel that present knowledge about succession is sufficient to permit us to make inferences about benthic processes from sediment profile images.

\section{REMOTE IMAGING}

Field studies described in this paper were done with the Rhoads-Cande Profile Camera (Rhoads and Cande, 1971; Fig. 2a). This camera has been used in benthic research for over $10 \mathrm{yr}$ (Rhoads and Young, 1970, 1971; Young and Rhoads, 1971; Rhoads, 1974; Bokuniewicz, et al., 1975). The camera differs from other underwater cameras by vertically slicing the sediment-water interface and viewing the sediment in profile. The organism-sediment relations illustrated in Fig. 1 can then be documented. For a detailed description of the mechanical operation of this instrument, see Rhoads and Cande (1971). This camera will be available on the commercial market through Ocean Instruments of San Diego, California, USA

We have recently developed a comparable profiling system (REMOTS) which incorporates a high-resolution video camera in the underwater housing above the wedge-shaped prism. This unit has the added modifi- cation of a water-injector on the back of the prism. The injector is connected to a 60 psi pump ( $\simeq 0.5$ GPM) on the support frame and is activated by a switch on the deck video monitor. Ambient seawater is forced into the bottom, fluidizing the sediment behind the prism. This enables the prism to penetrate hard-packed sands. The REMOTS system has many advantages: (1) It relays the sediment profile image to the deck monitor instantly, giving real-time data return. (2) The water-injector allows the system to be used in any type of granular bottom. (3) UV illumination can be combined with the appropriate camera filter to detect petroleum hydrocarbon contaminants in the sediment by the excited fluorescence. (4) The use of video signals to collect data (as opposed to still photography) permits a wide range of possiblities for data acquisition, storage, and image processing.

\section{SEDIMENT-PROFILE DATA}

A great deal of information about benthic processes is available from sediment-profile images. The data sheet reproduced in Table 1 shows the potential diversity of data that can be obtained from these photographs or video images

The biological data is limited to epifaunal or shallow infaunal organisms which are easily observed at the
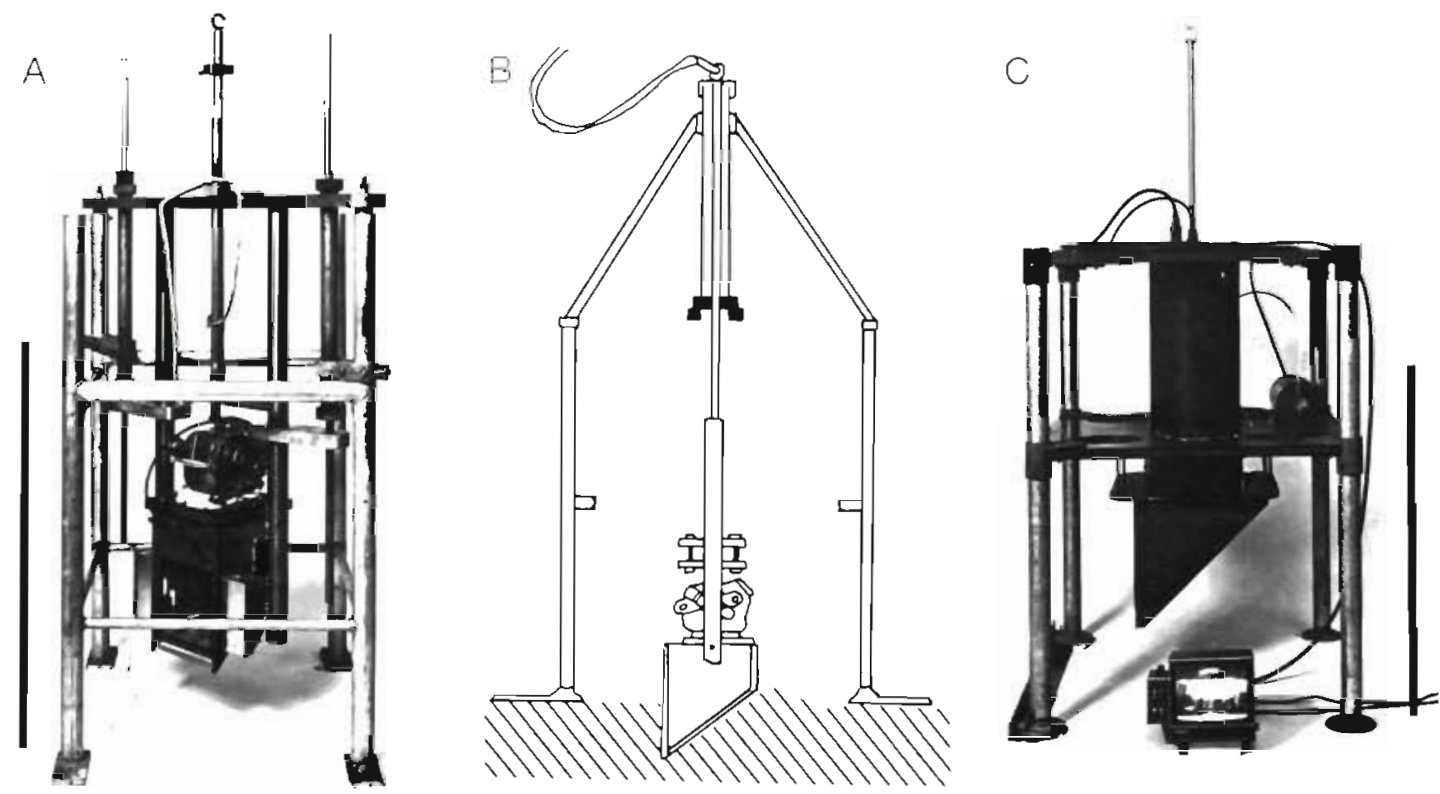

Fig. 2. (A) Rhoads-Cande Profile Camera used in shallow water ( $\leq 30 \mathrm{~m}$ ). Camera prism shown in 'up' position. This position is maintained as the instrument is deployed to avoid disturbance of the seafloor by a bow wave. Profile photographs in Figs. 3,4 , and 5 were made with this system. Scale: $1 \mathrm{~m}$. (B) Diagrammatic cross-section of prism in 'down' position transecting the sediment-water interface. The prism is released from up position when tension is released on winch wire. Rate of fall $\left(=6 \mathrm{~cm} \mathrm{~s}^{-1}\right)$ is controlled by oil-filled cylinders. Sediment displaced by the instrument is moved up the back side of the prism. Internal strobes provide illumination. (C) New REMOTS video profile camera developed for $330 \mathrm{~m}$ depth. Video signal transmitted to ship and displayed on video monitor. This instrument was engineered and constructed by Endeco, Inc., Marion, Massachusetts, USA 
Table 1. Sample sediment-profile photogrammetry data sheet

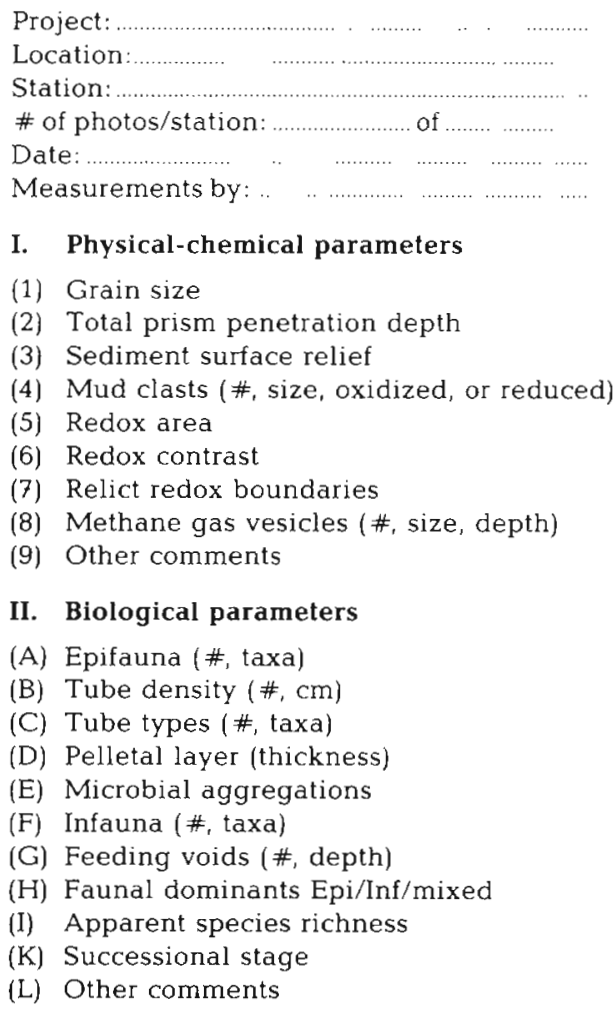

I. Physical-chemical parameters

(1) Grain size

(2) Total prism penetration depth

(3) Sediment surface relief

(4) Mud clasts (\#, size, oxidized, or reduced)

(5) Redox area

(6) Redox contrast

(7) Relict redox boundaries

(8) Methane gas vesicles (\#, size, depth)

(9) Other comments

II. Biological parameters

(A) Epifauna (\#, taxa)

(B) Tube density $(\#, \mathrm{~cm})$

(C) Tube types (\#, taxa)

(D) Pelletal layer (thickness)

(E) Microbial aggregations

(F) Infauna (\#, taxa)

(G) Feeding voids (\#, depth)

(H) Faunal dominants Epi/Inf/mixed

(I) Apparent species richness

(K) Successional stage

(L) Other comments

sediment surface. These are usually Stage 1 and Stage 2 species (Fig. 3a, b). Infaunal deposit-feeding species (Stage 3) may not be visible, but their presence can be inferred from their effects on sediment structure, e.g. subsurface feeding pockets (Fig. 3c) or surface layers of fecal pellets. Stage 3 species depress the redox boundary to depths greater than $2 \mathrm{~cm}$. The redox may locally extend to depths of $10 \mathrm{~cm}$ or more.

In addition to biological data, information about physical and chemical parameters is also available. Interpretation of sediment texture can be made from visual estimates of grain size distribution (the present photographic system allows resolution of particle diameters as small as $0.06 \mathrm{~mm}$ ). In many cases it is possible to designate major and minor sediment textural modes by comparing the imaged sediment with a standard Udden-Wentworth grain size comparator. The camera prism also acts as a static load penetrometer; because sands have higher bearing capacities than muds, camera penetration is always less in arenaceous sediments.

Presence or absence of dissolved oxygen in the overlying water can often be estimated from presence or absence of a redox boundary in the sediment (Fig. $4 \mathrm{a}$, c). In the presence of oxygen and the absence of a pumping macrofauna, the redox boundary will be
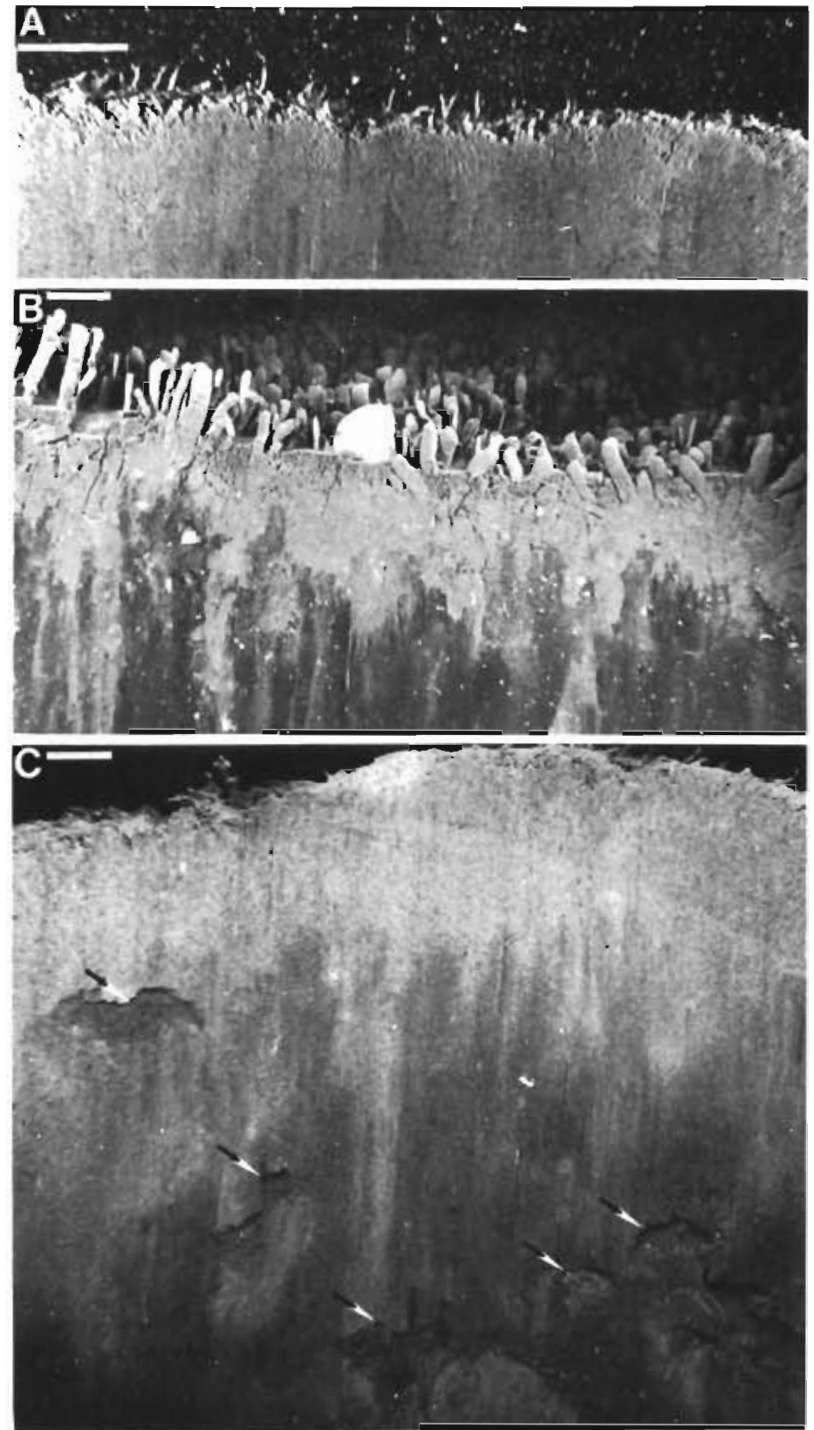

Fig. 3. Profile photographs of Stage 1, 2, and 3 succession in Long Island Sound. Horizontal bars equal $1 \mathrm{~cm}$. (A) Stage 1 succession consisting of a dense assemblage of small tubicolous polychaetes. Densities usually exceed 10 individuals $\mathrm{cm}^{-1}$ as measured horizontally along the profile transect. Species richness (tube diversity) is low. (B) Stage 2 succession dominated by tubicolous amphipods (Ampelisca abdita). This stage may also contain tubiculous or errant polychaetes and small opportunistic bivalves such as Mulinia lateralis and Tellina agilis. (C) Stage 3 succession dominated by infaunal deposit feeders. Presence of most infauna deduced from sedimentary evidence of their 'head-down' feeding. This can be seen in the form of feeding pockets (arrows). The pocket typically has a more-or-less planar 'roof' and a concave floor. The cavity may be filled with coarse-grained particles (an uningestible size fraction?)

limited to a diffusional depth of $1-2 \mathrm{~mm}$ in finegrained muds (Rhoads, 1974). At low partial pressures of oxygen, no redox boundary can be observed and one can assume the water column immediately above the bottom is reducing (Fig. $4 \mathrm{a}, \mathrm{c}$ ). Evidence of subsurface 
anderobic organic decomposition is indicated by the presence of methane gas bubbles in the sediment (Fig. $4 a, b)$. Anaerobic bacteria commonly utilize 3 different types of electron acceptors: $\mathrm{NO}_{3}{ }^{-}, \mathrm{SO}_{4}{ }^{-2}$, and $\mathrm{CO}_{2}$. Because nitrogen and sulphur atoms have a higher
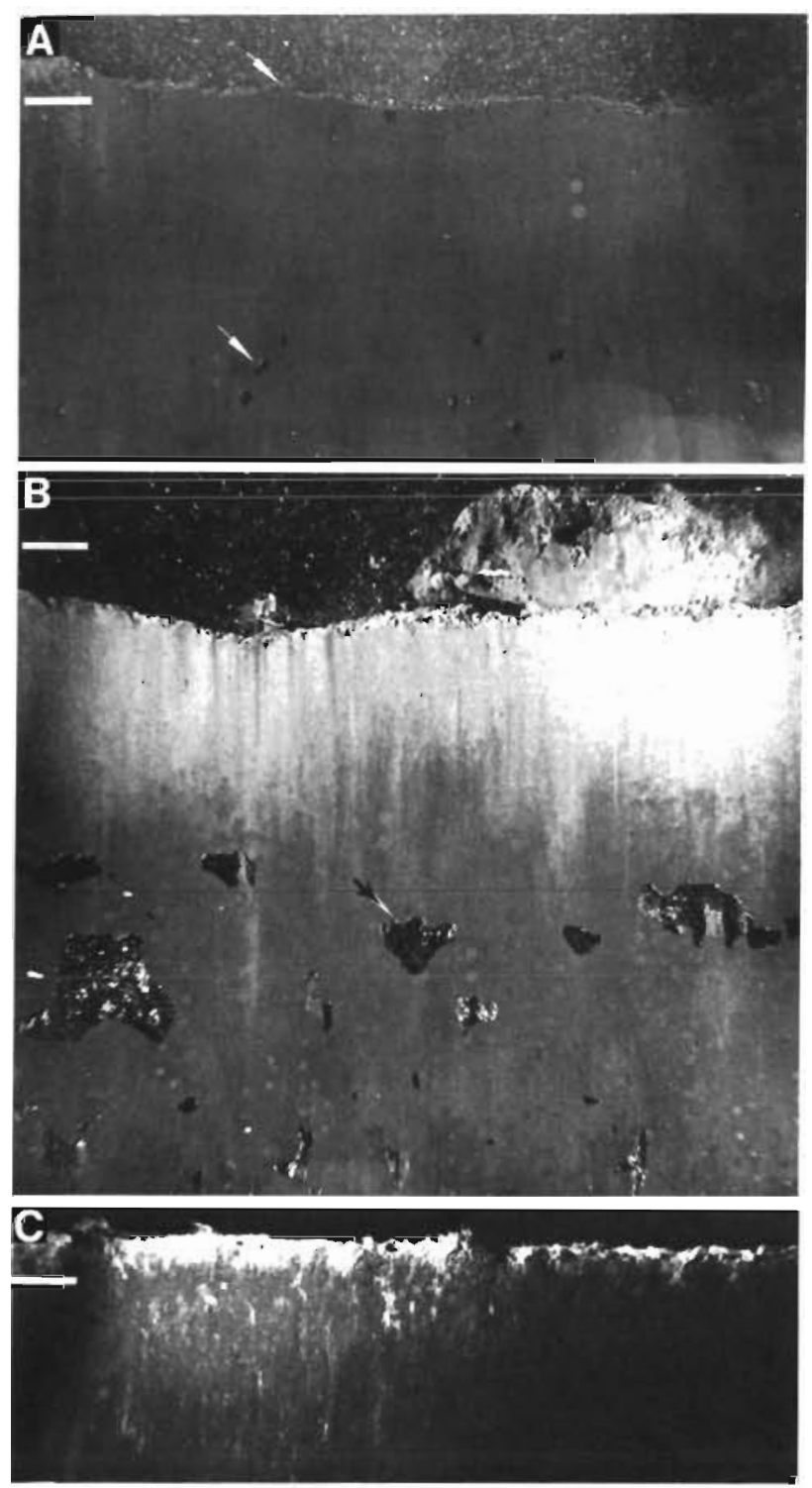

Fig. 4. Profile photographs of poorly-aerated bottom water (A and $C$ ) and methane production in organic rich sediments ( $A$ and B). Horizontal bars: $1 \mathrm{~cm}$. (A) Organic-rich mud with low $\mathrm{pO}_{2}$ in overlying water column. No redox boundary near sediment surface (upper arrow). Small methane gas pockets $3 \mathrm{~cm}$ (lower arrow) below sediment surface. (B) Aerobic bottom in Stage 1 succession. RPD at about 1 to $2 \mathrm{~cm}$ below surface. Below RPD, large methane pockets (arrow). Nassarius trivittatus is grazing to the left of a large mud clast. Surface of mud clast reduced, suggesting that the clast was recently eroded from below the RPD, transported to this site, and deposited on top of the aerobic surface. (C) Anoxic bottom covered with a surface layer of filamentous bacterial colonies (Thiobacilli?) electron affinity than carbon, bacteria sequentially utilize these substrates in the above order. Sometimes surface layers of anaerobic bacteria can be observed at the sediment-water interface (Fig. 4c). In sediments with relatively low organic inputs and high rates of biologic mixing (supplying pore water with renewed substrates), microbial degradation usually only involves utilization of $\mathrm{NO}_{3}$ and $\mathrm{SO}_{4}$. However, in sediments with high organic loading and where biologic mixing is not important, pore water concentrations of $\mathrm{NO}_{3}$ and $\mathrm{SO}_{4}$ can be depleted, giving rise to $\mathrm{CH}_{4}$ production.

Direct evidence of physical disturbance can be observed in profile images in the form of traction-load structures (active ripples; Fig. 5a), bottom scour resulting in shell-lag deposits (Fig. 5b), mud clasts (Fig. 4b) at the sediment surface, or exposed skeletal parts of infaunal organisms which are in life position (Fig. 5c) A retrograde succession can sometimes be detected when a Stage 1 faunal assemblage is associated with a shallow RPD overlying a deeper and darker 'relict' redox boundary. This rebounded redox phenomenon is shown in Fig. $5 \mathrm{~d}$ and $\mathrm{e}$.

Sediment profile imaging has the ability to relay a wide variety of information not available through traditional bottom sampling in a short amount of time. This makes it a particularly attractive system for a number of problems. The following section illustrates its application in 3 field studies; we describe its use to detect spatial and temporal gradients in disturbance (pollution and anoxia) and as a reconnaissance tool to decide the most parsimonious sampling scheme in a seafloor mapping project.

\section{FIELD STUDIES}

\section{Characterization of an Estuarine Pollution Gradient}

A transect study was undertaken in Narragansett Bay, Rhode Island from 1975 to 1976 by the EPA Water Quality Laboratory to determine which data, among 8 categories, gave the most information about the 'state of health' of the benthic environment:

(1) Quantitative and qualitative samples of the benthic macrofauna.

(2) Sediment Profile photography.

(3) Granulometry of the sediment.

(4) Neutron activation analyses of the bulk composition of the sediments.

(5) Analysis of acid-leachable metals from the sediments.

(6) X-radiography of box cores to characterize sedimentary fabrics.

(7) Analysis of carbon and nitrogen content of the sediment. 

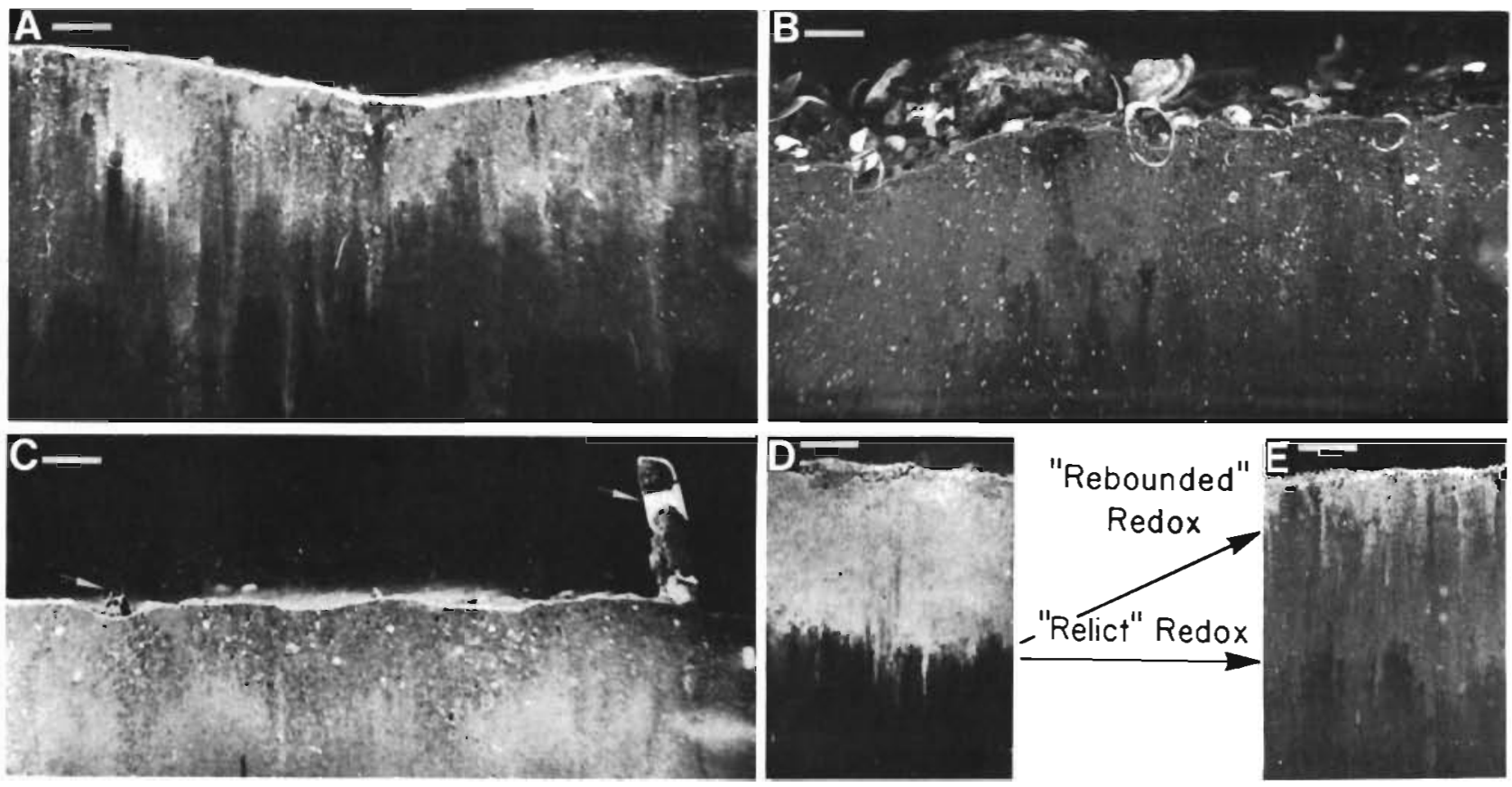

Fig. 5. Sediment profile evidence of physical bottom disturbance or retrograde succession. Horizontal bars: $1 \mathrm{~cm}$. (A) Symmetrical ripple with coarse sand and shell in the ripple trough. The redox has rebounded upward (see Fig. 5d). (B) Shell-lag deposit formed by sediment resuspension. (C) Evidence of net sediment erosion. A dead specimen of Ensis directus, a deep-burrowing bivalve, in its 'life' position with mud still adhering to the shell (right-hand arrow). The agglutinated sand tube of a dead errant infaunal polychaete, Pectinaria gouldii, partially eroded from sediment surface (left-hand arrow). A minimum of $2.5 \mathrm{~cm}$ of surface sediment has recently been eroded from this site. (D) A $3 \mathrm{~cm}$ deep RPD overlying an organic-rich mud (a late Stage 1 succession). (E) Retrograde succession. RPD has rebounded to within a few $\mathrm{mm}$ of the sediment surface. The former RPD can be observed at depth as a 'relict'

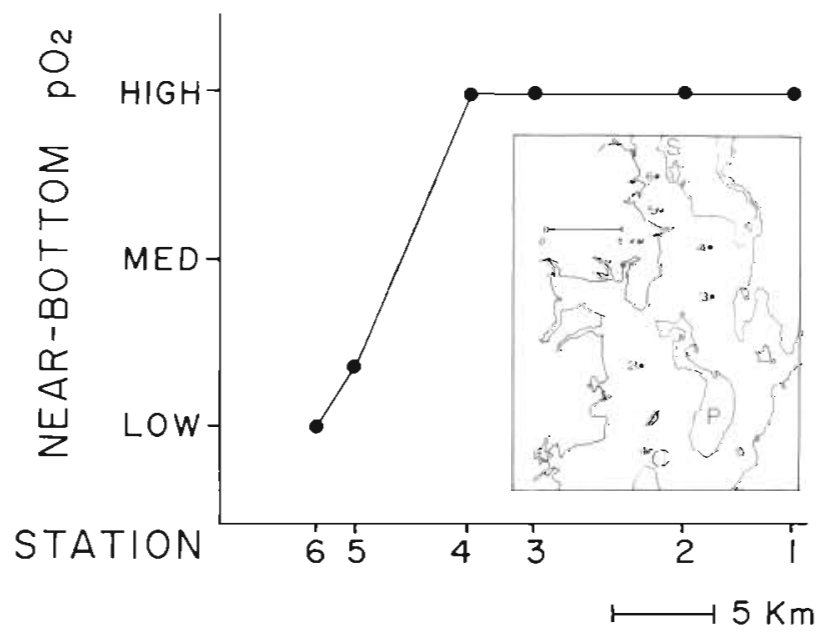

Fig. 6. Relative concentrations of dissolved oxygen in the water immediately above the bottom as deduced from profile photographs (from Myers and Phelps, 1978). Criteria as in Fig. $4 \mathrm{~A}, \mathrm{C}$ and accompanying text. Inset shows location of the 6 EPA benthic monitoring stations in Narragansett Bay. S: Sabin Pt.; P: Prudence Island; C: Conanicut Pt.
(8) Dissolved oxygen, $\mathrm{pH}$, salinity, and dissolved metals in the overlying water.

Six stations were sampled along a transect extending from Sabin Point, in the Providence River, to Conanicut Point, in the middle of Narragansett Bay (Fig. 6). The stations were occupied on October 28, 1975, March 19, 1976, and July 2, 1976. Three replicate photos were taken at each station. Interpretation of the photographs was done independently by the senior author (DCR) without prior knowledge of the results of the other measurements taken by the EPA.

Thirteen parameters were estimated or measured from the profile photographs. Five of these were found to be most useful for characterizing the estuarine gradient: (1) Sediment type, recorded as either muds or sands. (2) Near bottom dis s o lved oxy $\mathrm{g}$ e $\mathrm{n}$, based on the presence or absence of an aerated sedimentary surface (Fig. 6). (3) Concentration of near surface metal sulphides*, estimated by grey scale contrast of the sediment, especially the contrast between aerated surface and underlying reduced sedi-

- This inference is based on the positive correlation between organic carbon (grey-scale contrast) and trace metal concentrations in nearshore sediments (Applequist et al., 1972) 
NEAR-SURFACE METAL SULPHIDES

A
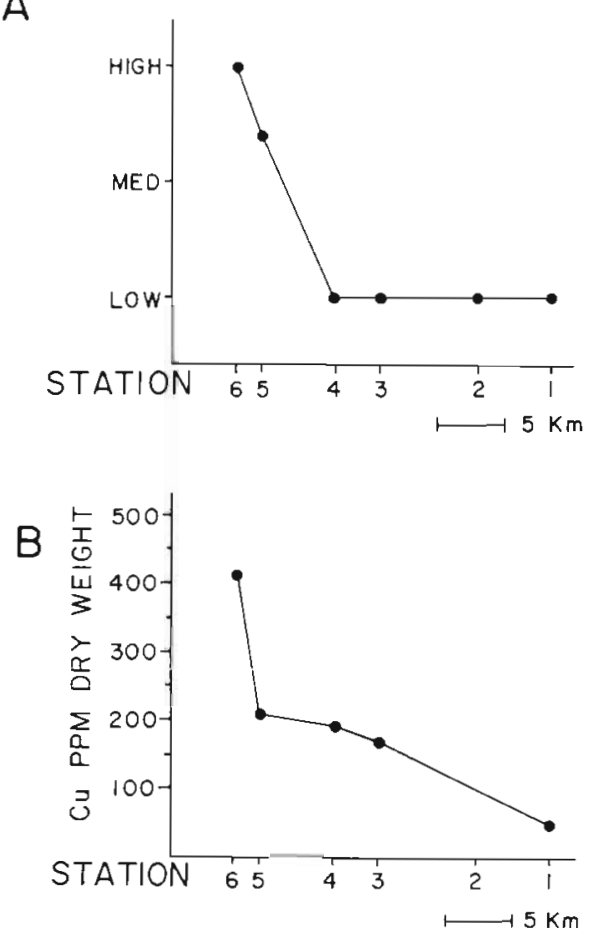

Fig. 7. Concentration of near surface metal sulphides (from Myers and Phelps, 1978). (A) Relative concentration gradient along sampling transect as inferred from grey scale contrast between aerobic and anaerobic sediments in late October. (B) Acid-leachable copper in sediments as measured along Narragansett Bay transect in late summer

ments (Fig. 7a, b). (4) Species richness, estimated by the number of tube types of epifauna or shallow infauna and evidence of deep infauna such as subsurface feeding voids or burrows of errant species (Fig. 8a, b). (5) Sediment penetrability or compactness, measured with a set of static load penetrometers (Bokuniewicz et al., 1975) fitted onto the face of the camera prism.

Three major biofacies were identified from the profile camera survey based on the inferred species richness (Fig. 8a). Species richness, determined from grab samples along the transect (Fig. 8b), generally corresponds to that inferred from the photographs. Stations 5 and 6 are clearly distinct from all other stations in species richness as well as dissolved oxygen (Fig. 6) and metal sulphides (Fig. $7 \mathrm{a}, \mathrm{b}$ ).

Inferences made from the profile photographs about the estuarine pollution gradient were subsequently verified by ground-truth sampling. The reconaissance camera study suggests that the 'health' of such a benthic transect can be remotely detected. An unstressed benthic mud-dwelling community in summer is reflected by high sediment compactness, photo-
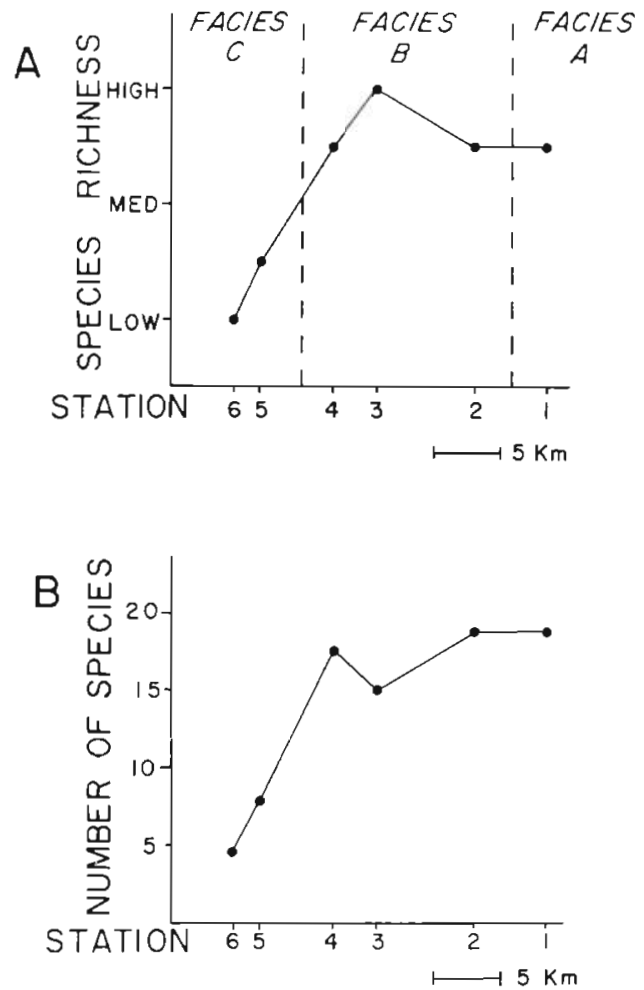

Fig. 8. Species richness along Narragansett Bay transect (from Myers and Phelps, 1978). (A) Species richness in late October as inferred from sediment-profile photographs. Criteria as in Fig. 3. When the Narragansett Bay transect was photographed, the successional model presented in Fig. 1 and 3 did not exist, therefore the data are expressed as richness rather than successional sere. (B) Species richness in late summer as measured from benthic grab samples. Data expressed as total number of species obtained in 3 box cores. Sediments sieved to $0.5 \mathrm{~mm}$

graphic evidence of low concentrations of dark reduced sediment near the sediment surface, a deeplyaerated surface sediment, and high species richness.

Myers and Phelps' (1978) summary report concludes that of all the measures made to characterize the benthic transect, 'the interface camera, and acid leachable metals together with sediment granulometry, were considered the most useful for assessing benthic health for making management decisions involving dredged material.'

\section{Monitoring the 'August Effect' in New Haven Harbor}

The profile camera has been used to monitor the impact of the United Illuminating Company's fossil fuel generating plant ( $460 \mathrm{MW}$ ) on the benthos of New Haven Harbor, Connecticut. Prior to employing the camera as a routine monitoring tool, the harbor benthos were sampled with a grab from 1975 to 1978 at 
26 stations occupied in February, March, June, August, October, and December (McCusker and Bosworth, 1979). From this macrofaunal data base, a subset of 8 stations was identified as providing the most information about faunal change within the harbor. The August sampling period was found to be especially informative; the inner harbor is subjected to low levels of dissolved oxygen in August, related to high ambient water temperatures, low mixing rates in the water column, and high rates of organic decomposition related to the proximity of two municipal sewage effluents.

Starting in 1979, the profile camera was used to document this 'August Effect'. Three replicate photographs were taken at each of the 8 stations in early and late summer and fall. Normandeau Associates " continued to collect benthic grabs at these 8 stations. The camera and grab-sampling data sets were not compared until the 2 summary reports were independently prepared and submitted.

Fig. 9 is a comparison of the 'August Effect' in 1979 and 1980. All data in this figure were obtained remotely with the profile camera. The 3 Morris Cove stations in the outer harbor were established as reference sites, because they were removed from point sources of municipal pollution.

Four of the inner harbor stations showed the presence of methane $"$ in the sediment in August, 1979 (Fig. 9a). Two of these 4 stations also showed sedimentary evidence of low concentrations of oxygen in the bottom water, as well as the 1 station located in the ship channel. Only 1 station in Morris Cove showed sediment methane. Two inner harbor stations were azoic (no apparent macrofauna $\geq 1.0 \mathrm{~mm}$ ) while the other 6 stations were in Stage 1 succession (pioneering polychaete assemblage; Fig. 9b).

In 1980, only 2 inner harbor stations showed the presence of sediment methane, and 1 station located in the ship channel showed sedimentary evidence of low concentrations of oxygen in the bottom water. The 5 remaining stations were aerobic and no apparent methane was observed (Fig. 9c). All inner harbor stations were in Stage 1 succession, except 1 replicate of the channel station which had reached a Stage 2 (amphipod) sere. Two of the Morris Cove stations had also attained Stage 2 succession in August (Fig. 9d).

The grab sampling program confirmed the 1979 interpretations made from the camera survey (Bosworth et al., 1980). The harbor profile camera survey suggests that while the 'August Effect' was present in both 1979 and 1980, its impact was less severe in 1980

- Bedford, New Hampshire, USA

- Gas pockets $<1.0 \mathrm{~mm}$ in diameter cannot be resolved in the profile photographs
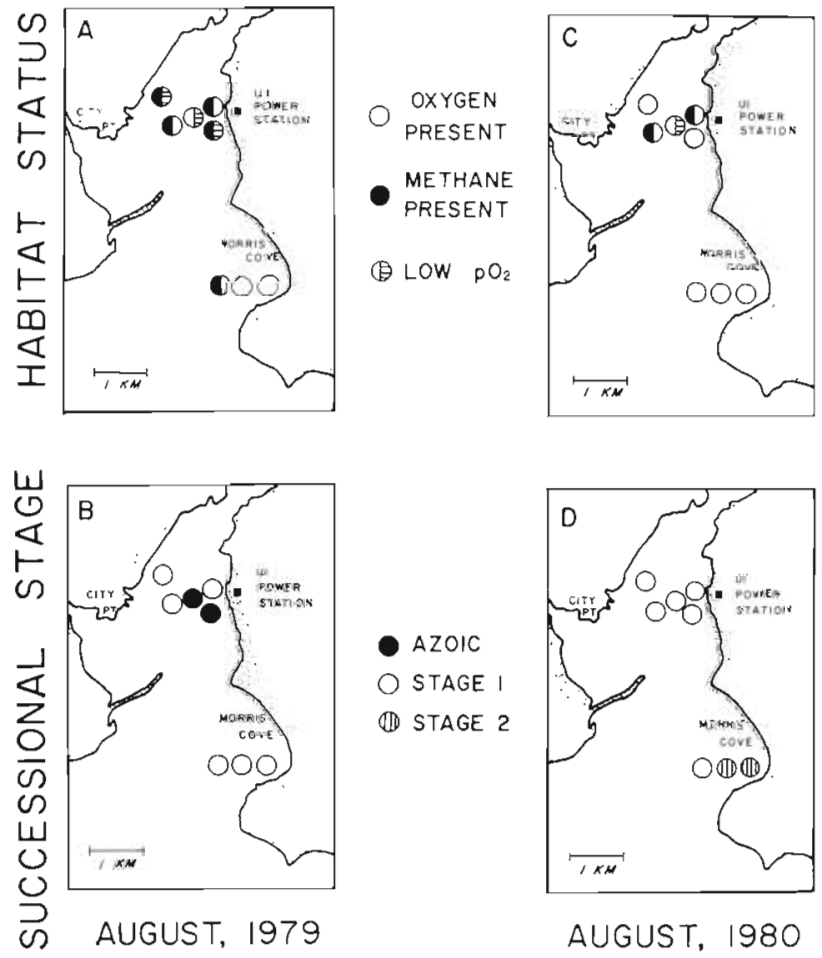

Fig. 9. Comparison of 'August Effect' in New Haven Harbor between 1979 and 1980 using profile photography. Interpretation based on 3 replicate photographs at each station. (A) Habitat conditions during August, 1979. Stations mapped as anoxic or methanogenic if 2 or 3 replicate photographs showed low levels of dissolved oxygen or methane bubbles. Criteria as in Fig. 4. (B) Successional status of harbor benthos during August, 1979. Successional mapping based on dominant sere present. (C) Habitat conditions during August, 1980. Stations mapped as anoxic or methanogenic if 2 or 3 replicate photographs showed low levels of dissolved oxygen or methane bubbles. (D) Successional status of harbor benthos during August, 1980. Successional mapping based on dominant sere present

than in 1979. The improvement in the harbor fauna in 1980 relative to 1979 was also confirmed by the grab sampling (McCusker and Bosworth, 1981). The harbor monitoring in 1979 and 1980, as interpreted from both the camera survey and grab samples, did not detect any measurable impact of the thermal effluent on the benthos of New Haven Harbor.

Routine monitoring of many harbor perturbations does not, in many cases, require taking benthic samples. The camera is capable of detecting faunal changes and can, in many instances, identify specific habitat changes that may be related to the observed change in fauna. However, if the camera survey detects an unusual excursion in established patterns of succession or bottom disturbance, ground truth sampling may be in order to document the phenomenon in greater detail. 


\section{Reconnaissance Seafloor Mapping}

In order to determine benthic habitat conditions prior to manipulative field experiments, 1.5 square miles of the seafloor were surveyed in Long Island Sound (FOAM station) ' on August 28 and November 5 , 1980, using sediment profile photography (Fig. 10). This area $\left(41^{\circ} 14^{\prime} \mathrm{N}, 72^{\circ} 45^{\prime} \mathrm{W}\right)$ is located southeast of

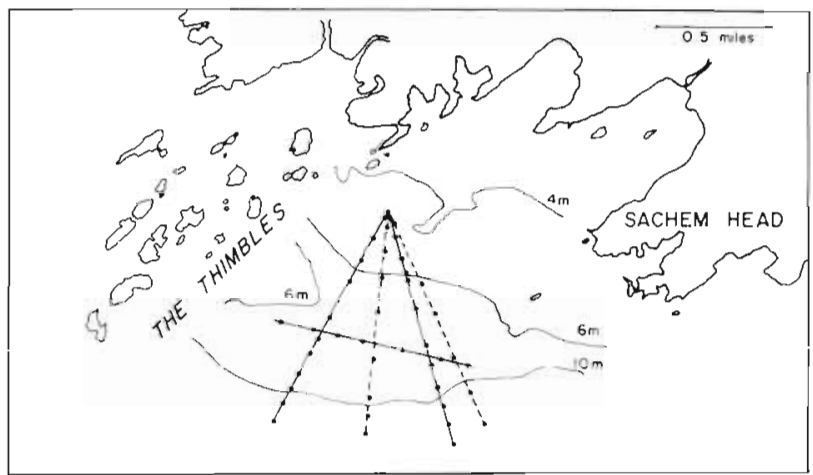

Fig. 10. Sampling transects for August and November, 1980, located off Guilford, Connecticut (northern coast of Long Island Sound). The 2 dashed lines represent transects occupied in August, the 3 solid lines represent transects occupied in November. Dots: locations where profile photographs were taken

the Thimble Islands off Guilford, Connecticut. Transects were run using a compass course with land range markers, and photographs taken at approximately $1 \mathrm{~m}$ depth intervals as indicated by the boat's fathometer. A total of 46 photographs were taken during the 2 sampling days. Estimates of sediment grain size, sediment water content (camera penetration depth), area of aerated sediment above the RPD, substratum stability (e.g. Fig. 5), oxygen content of bottom water, depth of bioturbation, and successional stage of the benthic infauna were made from the photographs.

Data subsets from photographic measurements were mapped (Figs. 11 to 13). Fig. 11 shows that the area consists mainly of muddy sands (arenite) with 3 smaller areas of mud (lutite). Estimates of physical disturbance of the bottom (Fig.12) showed a marked contrast in bottom conditions between the 2 sampling times. Note that the area of bottom undisturbed in August is physically disturbed in November.

Fig. 13 illustrates the comparison between thickness of aerobic surface sediments and successional stage. The successional stage indicated by the area marked

\footnotetext{
- Station FOAM is located near McCall's (1977) Site $A_{i}$ it is the location of intensive geochemical investigations and is appropriately named 'Friends of Anoxic Muds' (FOAM) (Goldhaber et al., 1977)
}

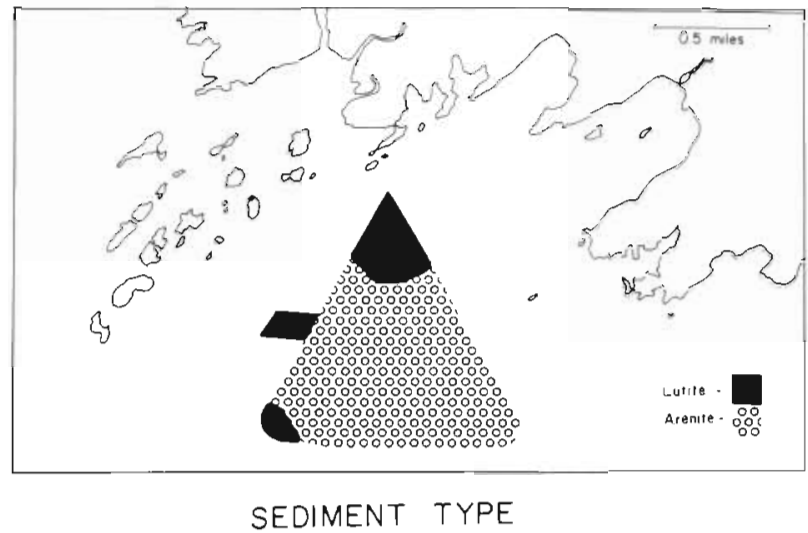

Fig. 11. Sediment type mapped from visual estimates of grain size distribution from photographs. Criteria as outlined in text
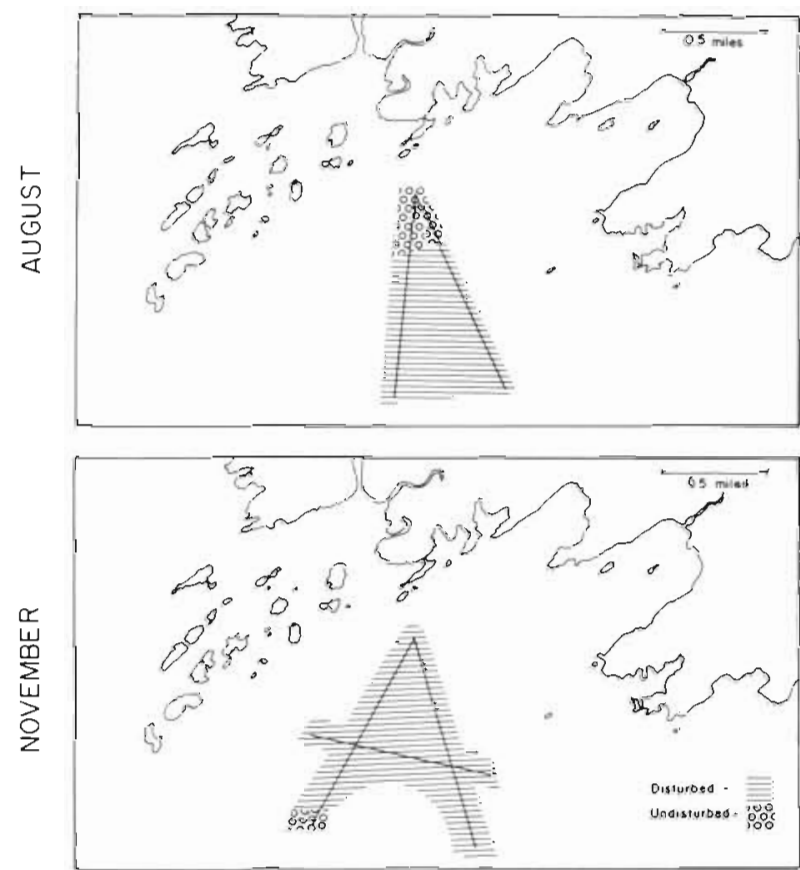

PHYSICAL DISTURBANCE

Fig. 12. Mapped areas showing evidence of bottom disturbance (criteria in text). Note shift in conditions between the 2 sampling periods

'Stage 1 ' in August is an area dominated by the small, rapidly growing bivalve Mulinia lateralis (Mactridae), an early pioneer on disturbed bottoms. Present in high densities $\left(50,000 \mathrm{~m}^{-2}\right)$, these bivalves are packed 3 to 5 individuals deep and bioturbate the sediments to a depth of approximately 3 to $5 \mathrm{~cm}$, increasing the sediment water content and locally excluding pioneering tubicolous polychaetes by their 'bulldozing' activities (sensu Thayer, 1979).

The profile camera survey illustrates how smallscale spatial and temporal changes in the bottom can 

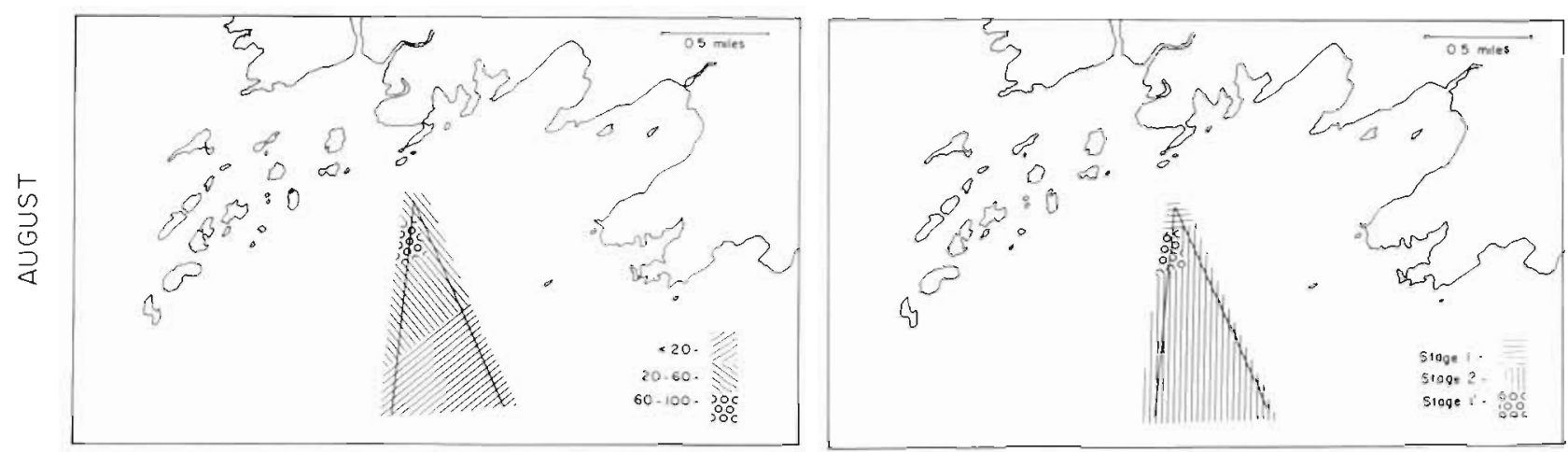

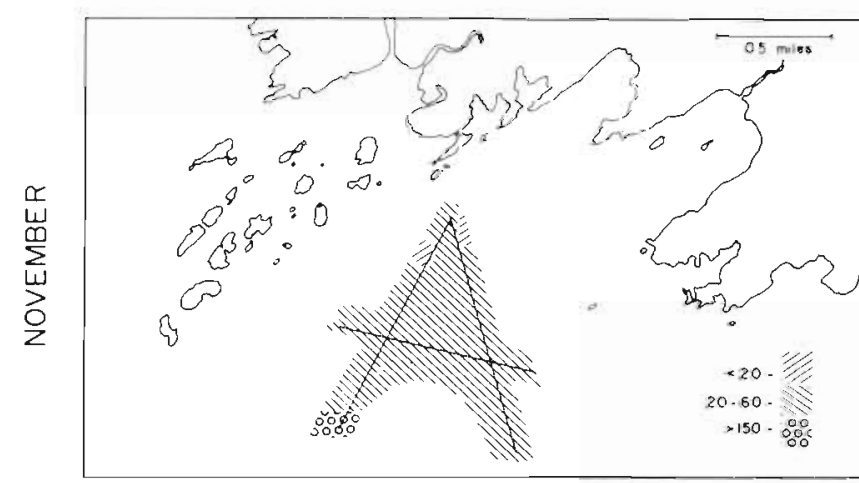

RPD AREA $\left(\mathrm{cm}^{2}\right)$

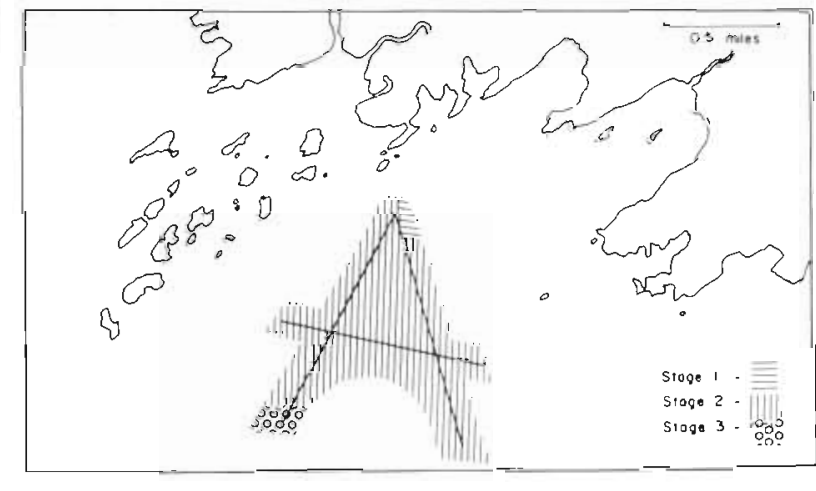

SUCCESSIONAL STAGE

Fig. 13. Maps showing area of aerobic sediment above redox boundary (RPD area) in August and November compared with successional stage of the infauna

be characterized in a short period of time. The only information an investigator may have about an area of seafloor prior to sampling is that recorded on a navigational chart. Anyone who has worked from these charts has found that the sediment type marked on the chart may not be present. The area surveyed in this study was marked on the navigational chart (NOAA \#12373) as being primarily a 'soft' bottom, with one small 'hard' area occupying a small section in the middle of the transect pattern (Fig. 10). This was not the case, as can be seen in Fig. 11

A comparison of Figs. 12 and 13 shows the relationship of physical disturbance, depth of RPD, and successional stage. Areas experiencing frequent erosion will never reach a Stage 3 succession; local bottom scour, which removes surficial aerobic sediment, makes the RPD appear to be closer to the sediment surface. The Mulinia patch associated with surface bioturbation (August, Fig. 13) experienced greater erosion in November than the surrounding bottom. This is portrayed by the patch of shallow RPD seen in that area in November (Fig. 13).

The most striking aspect of the survey is that the patchiness for many of the parameters is on a much smaller scale than one might initially suppose from the hydrographic chart. Traditional grab sampling methods would have probably missed this patchiness. The portrayal of the area as a temporal and spatial mosaic for many parameters is not surprising when one considers the frequency of disturbance for nearshore marine benthic habitats.

\section{DISCUSSION}

Because of the high cost involved in traditional benthic surveys, an important initial decision about size and number of samples has to be made; too small a sample will yield data of little use, too large a sample will be a waste of resources. Statistical sampling theory can be applied to give a first approximation of the number of samples which must be taken from a given population. To do this, some arbitrary decisions first have to be made about the desired degree of precision for the items to be measured in the population.

A formula for estimating sample size $\left(n_{0}\right)$ from random sampling (Cochran, 1977) is:

$$
n_{0}=\frac{t^{2} S^{2}}{r^{2} \bar{Y}^{2}}
$$

where: $t=$ abscissa of the normal curve that cuts off an 
area of $\alpha$ (the risk that the margin of error will be larger than specified) at the tails; $S=$ population standard deviation; $r=$ relative error in the estimated population total or mean; $\bar{Y}=$ population mean of the parameter to be measured. ( $S / \bar{Y}$ is also known as the coefficient of variation for $n$ ).

The investigator is then confronted with another problem: a formula for $n$ is available but depends on some properties ( $S$ and $\bar{Y}$ ) of the population to be measured. There are ways of estimating the population mean and variance (results from a pilot survey, previous sampling of similar populations, or educated guesswork) for the parameters being measured. This brings another source of conflict to light: if more than 1 parameter (e.g. number of individuals $\mathrm{m}^{-2}$, number of species $\mathrm{m}^{-2}$, grain-size distribution of sediments, etc.) is being measured in the survey (as is commonly the case), calculations can lead to a series of conflicting values for $n$, one for each parameter. There are formulae for dealing with this situation (Cochran, 1977 : Chapter 4), but the investigator must then decide if the value obtained for $n$ is feasible given the available time and funding. If not, then the decision must be made to take smaller samples (reducing precision) or to wait for additional funds.

Even if one goes through all of the above mentioned procedures (regardless of whether the value obtained for $n$ is reasonable), the underlying assumption is that one is sampling from a steady-state system. Obtaining a population mean and variance in a pilot sampling study from an area of undisturbed muddy bottom with Stage 3 successional infauna will be of little use when sampling a sandy disturbed bottom of Stage 1 infauna (a change in either $S$ or $\bar{Y}$ will affect $n$ ). One could theoretically sample an area intensively enough with grabs to account for all the potential patchiness and then decide on the most parsimonious sampling scheme. However, given the time lag on data return with traditional sampling methods, the chances are high that the predicted sampling strategy would be inapplicable by the time one returned to the area. Using sediment profile imaging, an investigator can quickly document changes in bio- and lithofacies over time and space, identifying the areas where benthic sampling should be concentrated and at what scale. Statistical sampling theory can then be applied to give meaningful results about sample adequacy.

Sediment profile imaging is not intended to eliminate grab sampling, but rather serves to establish a parsimonious grab sampling program or as an alternative monitoring tool. Once a baseline bottom sampling survey of an area has been done and a species list assembled, there are many routine monitoring problems that can be addressed without repeated compilation of faunal lists; it may prove sufficient to identify the stage of succession of the benthic fauna and its subsequent development or destruction.

The advantages of using sediment-profile imaging as opposed to traditional sampling methods are many. The use of grabs or dredges destroys the in situ relationships of organisms to their sedimentary matrix and to one another (either in the sampling process or the processing of the sample). Sample processing methods (sieving, staining, sorting, and species identification) are extremely labor-intensive; therefore, data return is slow and expensive. Organism-sediment relations are readily observable in sediment profile images; data acquisition is fast and, due to the camera's design, never limited by water turbidity.

Using either photographs or the video REMOTS system, one can also store a large amount of data in a very small amount of space. Negatives and photographs or video cassette tapes can be easily filed and quickly referred to, as opposed to archived sample jars.

Image interpretation is orders of magnitude quicker than traditional processing methods. Taking measurements by hand from sediment profile photographs, we recently were able to analyze and map the results of a complete harbor survey (66 stations sampled each at 2 different times) in less than 1 wk. Data interpretation and storage is being further advanced with the video REMOTS system. The use of a video signal to collect the data as opposed to still photography allows real time data acquisition, along with the ability to digitize, process, and store the image with a computer image analysis system. A complete image analysis system to go with the video camera is being developed in cooperation with Measuronics Corporation of Great Falls, Montana, USA. Image analysis will allow many of the parameters shown on Table 1 to be calculated immediately; a large number of images can be stored, with earlier images from a particular station retrieved and compared instantly. Such a data management system would be used to generate maps or graphs (similar to those shown in Figs. 6 to 13) as the survey was taking place. The REMOTS system could be a cost-effective tool for monitoring dredge-spoil projects or outer continental shelf drilling activities.

Gray (1976) criticized most marine baseline surveys as 'a waste of both manpower and money'. He also cited the inadequacy of theoretical frameworks, at the time when his paper was written, for interpreting the results of such surveys. Mills (1975) called benthic ecology 'a rather shabby and intellectually suspect branch of biological oceanography. Its methods are, for the most part, those of the nineteenth century... Assembling a species list is not only extremely time consuming, but in many cases is an information overkill for the problem addressed. There is no need for benthic ecologists to continue to rely primarily on 
sampling methods used during the Challenger expedition. Using the successional model for interpretation of organism-sediment relationships (Rhoads and Boyer, 1982), we have shown how sediment profile imaging can be used as a monitoring tool to detect spatial and temporal gradients in benthic disturbance or as a reconnaissance tool to aid in the design of benthic sampling programs. The ease of sampling and the elimination of the time lag on data return are the system's most powerful assets. The REMOTS system can document alterations in benthic habitats over a large area of seafloor in a short time. Previous work (Myers and Phelps, 1978; Bosworth et al., 1980) has shown that this system will produce results significantly similar to conventional benthic sampling. Given the added advantages of quick data return and preservation of organism-sediment relationships, we feel that sediment profile imaging is a powerful, versatile technique that can aid any benthic investigation.

Acknowledgements. Some aspects of this work were supported by NSF grant OCE 7826211. We wish to thank L. Boyer, D. G. Cook, L. Levin, D. K. Muschenheim and S. Twombly for their constructive criticism of this manuscript. Mike Pimer (Professional Sea Services) and Larry Boyer helped us deploy the camera system in the New Haven Harbor and Thimble Islands projects, and Andrew McCusker and David Hartzband (Normandeau Associates) undertook the ground truth study in the harbor project.

Allan Myers and Donald Phelps encouraged the senior author to participate in the EPA transect study in Narragansett Bay.

We thank Edward Brainard of Endeco for taking interest in our REMOTS project and for the construction of the prototype video system.

\section{LITERATURE CITED}

Aller, R. C. (1980). Relationships of tube-dwelling benthos with sediment and overlying water chemistry. In: Tenore, K. R., Coull, B. C. (eds.) Marine benthic dynamics. University of South Carolina Press, Columbia, pp. 285-308

Aller, R. C. (1982). The effects of macrobenthos on marine sediment and riverine water. In: McCall, P. L., Tevesz, M. (eds.) Plenum Geobiology Series, Volume 2. Plenum Press, New York, in press

Applequist, M. D., Katz, A., Turekian, K. K. (1972). Distribution of mercury in the sediments of New Haven (CT) Harbor. Environ. Sci. Technol. 6: 1123-1124

Bagge, P. (1969). The succession of the bottom fauna communities in polluted estuarine habitats. Limnologica 7 : $87-94$

Bokuniewicz, H. J., Gordon, R. B., Rhoads, D. C. (1975). Mechanical properties of the sediment-water interface. Mar. Geol. 18: 263-278

Bosworth, W. S., Germano, J. D., Hartzband, D. J., McCusker, A. J., Rhoads, D. C. (1980). Use of benthic sediment profile photography in dredging impact analysis and monitoring. Presented at the Ninth World Dredging Conference, October 29-31, 1980. Vancouver, British Columbia
Cochran, W. G. (1977). Sampling techniques, John Wiley \& Sons, Inc., New York

Dayton, P. K., Oliver, J. S. (1980), An evaluation of experimental analyses of population and community patterns in benthic marine environments. In: Tenore, K. R., Coull, B. C. (eds.) Marine benthic dynamics. University of South Carolina Press, Columbia, pp. 93-120

Eckman, J. E., Nowell, A. R. M. Jumars, P. A. (1981). Sediment destabilization by animal tubes. J. mar. Res. 39 361-374

Golhaber, M. B., Aller, R. C., Cochran, J. K., Rosenfeld, J. K., Martens, C. S., Berner, R. A. (1977). Sulphate reduction, diffusion, and bioturbation in Long Island Sound sediments: report of the FOAM group. Am. J. Sci. 277: 193-237

Gray, J. S. (1976). Are marine base-line surveys worthwhile? New Scient. 70: 219-221

Johnson, R. G. (1972). Conceptual models of benthic marine communities. In: Schopf, T. J. M. (ed.) Models in paleobiology. Freeman, Cooper \& Co., San Francisco, pp. $149-159$

Jumars, P. A., Hessler, R. R. (1976). Hadal community structure: implications from the Aleutian Trench. J. mar. Res. 34: 273-282

McCall, P. L. (1977). Community patterns and adaptive strategies of the infaunal benthos of Long Island Sound. J. mar. Res. 35: 221-266

McCall, P. L. (1978). Spatial-temporal distributions of Long Island Sound infauna: the role of bottom disturbance in a nearshore marine habitat. In: Wiley, M. L. (ed.) Estuarine interactions. Academic Press, New York, pp. 191-219

McCusker, A. J., Bosworth, W. S. (1979). New Haven Harbor ecological studies summary report 1970-1977. Prepared for the United Illuminating Company, New Haven, Connecticut. Normandeau Associates, Inc., Bedford, New Hampshire

McCusker, A. J., Bosworth, W. S. (1981). New Haven Harbor ecological studies summary report 1980. Prepared for the United Illuminating Company, New Haven, Connecticut. Normandeau Associates, Inc., Bedford, New Hampshire

McIntosh, R. P. (1980). The relationship between succession and the recovery process in ecosystems. In: Cairns, J., Jr. (ed.) The recovery process in damaged ecosystems. Ann Arbor Science Publishers, Ann Arbor, pp. 11-62

Mills, E. L. (1975). Benthic organisms and the structure of marine ecosystems. J. Fish. Res. Bd Can. 32: 1657-1663

Moore, H. B. (1931). The muds of the Clyde Sea area. III. Chemical and physical conditions, rate and nature of sedimentation, and fauna. J. mar. biol. Ass. U. K. 17 : $325-358$

Myers, A. C. (1977). Sediment processing in a marine subtidal sandy bottom community: II. Biological consequences. J. mar. Res. 35: 633--647

Myers, A. C., Phelps, D. K. (1978). Criteria of benthic health: a transect study of Narragansett Bay, Rhode Island. Report to U. S. Environmental Protection Agency, Contract No. P. O. 53203

Pearson, T. H., Rosenberg, R. (1978). Macrobenthic succession in relation to organic enrichment and pollution of the marine environment. Oceanogr. mar. Biol. A. Rev. 16: 229-311

Pearson, T. H., Stanley, S. O. (1979). Comparative measurement of the redox potential of marine sediments as a rapid means of assessing the effect of organic pollution. Mar. Biol. 53: 371-379

Revsbech, N. P., Jorgensen, B. B., Blackburn, T. H. (1979). Oxygen in the sea bottom measured with a microelectrode. Science, N.Y. 207: 1355-1356 
Rhoads, D. C. (1974). Organism-sediment relations on the muddy sea floor. Oceanogr. mar. Biol. A. Rev. 12; 263-300

Rhoads, D. C., Aller, R. C., Goldhaber, M. (1977). The influence of colonizing benthos on physical properties and chemical diagensis of the estuarine seafloor In: Coull B. C. (ed.) Ecology of marine benthos. University of South Carolina Press, Columbia, pp. 113-138

Rhoads, D. C., Boyer, L. F. (1982). The effects of marine benthos on physical properties of sediments: a successional perspective. In: McCall, P. L., Tevesz, M. (eds.) Plenum Geobiology Series, Volume 2. Plenum Press, New York, in press

Rhoads, D. C., Cande, S. (1971). Sediment profile camera for in situ study of organism-sediment relations. Limnol. Oceanogr. 16: 110-114

Rhoads, D. C., McCall, P. L., Yingst, J. Y. (1978). Disturbance and production on the estuarine seafloor. Am. Sci. 66 $577-586$

Rhoads, D. C., Young, D. K. (1970). The influence of depositfeeding organisms on sediment stability and community trophic structure. J. mar Res. 28: 150-178

Rhoads, D. C., Young, D. K. (1971). Animal-sediment relations in Cape Cod Bay, Massachusetts. II. Reworking by Molpadia oolitica (Holothuroidea). Mar. Biol. 11: 255-261

Sanders, H. L. (1958). Benthic studies in Buzzards Bay. I. Animal-sediment relationships. Limnol. Oceanogr. 3: 245-258

Santos, S. L., Bloom, S. A. (1980). Stability in an annually defaunated estuarine soft-bottom community. Oecologia 46: 290--294

Santos, S. L., Simon, J. L. (1980). Marine soft-bottom community establishment following annual defaunation: larval or adult recruitment? Mar Ecol. Prog. Ser. 2: 235-241

Tenore, K. R., Corral, J., Garcia-Fernandez, C., Gonzalez, N., Gurrian, E. G., Hanson, R. B., Iglesias, J., Krom, M., LopezJamar, E., McClain, J., Pamatmat, M., Perez, A., Rhoads, D. C., Rodriguez, R. M., Santiago, G., Tietjen, J., Westrich, J., Windom, H. L., Boyer, L. F. (1982). Coastal upwelling in the Rias Bajas, N.W. Spain: contrasting the benthic regimes of the Ria de Arosa and de Muros. J. mar. Res., in press

Thayer, C. W. (1979). Biological bulldozing and the evolution of marine benthic communities. Science, N.Y. 203: 458-461

Wade, B. A. (1972). A description of a highly diverse softbottom community in Kingston Harbour, Jamaica. Mar. Biol. 13: 57-69

Yingst, J. Y., Rhoads, D. C. (1980). The role of bioturbation in the enhancement of microbial turnover rates in marine sediments. in: Tenore, K. R., Couli, B. C. (eds.) Marıne benthic dynamics. University of South Carolina Press, Columbia, pp. 407-421

Young, D. K., Rhoads, D. C. (1971). Animal-sediment relations in Cape Cod Bay, Massachusetts. I. A transect study. Mar. Biol. 11: 242-254

This paper was submitted to the editor; it was accepted for printing on January 19, 1982 